\title{
Artesanato, identidade e geração de renda: o caso da vila progresso, Caçapava do Sul/RS
}

\author{
Handicraft, identity and income growth: the case of vila progresso, \\ Caçapava do Sul/RS
}

\author{
Helena Maria Beling'; Dreisse Gabbi Fantineli"; Janete Webler Cancelier'II \\ Daiane Loreto de Vargas ${ }^{\text {IV }}$
}

\begin{abstract}
RESUMO
O presente estudo tem por objetivo compreender qual a contribuição do artesanato para a geração de renda no contexto de uma comunidade rural. Nesse sentido, destaca-se o cenário da comunidade rural da Vila Progresso, Caçapava do Sul/RS, onde foi realizado um estudo de caso, cuja metodologia foi baseada na abordagem qualitativa. Os referenciais teóricos utilizados na investigação propiciaram a compreensão do fenômeno analisado. Os dados primários foram coletados em trabalho de campo com conversas, observações da diversidade de produtos e as diferentes organizações, registro fotográfico e anotações em um diário de campo. Desde as primeiras peças artesanais de lã e as primeiras tendas até o presente momento várias foram as transformações, que dizem respeito à vida e aos produtos confeccionados e comercializados pelos artesãos da Vila Progresso. Como resultado, é notável a diversificação dos produtos artesanais e as trocas comerciais que foram se modificando ao longo do tempo, gerando uma reconfiguração nesta comunidade rural. Essas transformações foram geradas, sobretudo, pela necessidade de suprir e atrair o mercado consumidor, relacionando assim, o artesanato, a identidade e a geração de renda.
\end{abstract}

Palavras-chave: artesãos; comunidade rural; mercado simbólico; saberes tradicionais; tendas

\begin{abstract}
The following paper aims to comprehend the handicraft contribution to the income growth in the context of the rural community of Vila Progresso in the city of Caçapava do Sul/RS, where a case study was performed, through the use of a methodology based on a qualitative approach. The theoretical references used in the investigation provided an understanding of the analyzed phenomenon. The primary data were collected through conversations, observation of products diversity and different organizations, photographic registers and notes taken in a field diary. The life and products made and sold by the craftsmen of Vila Progresso have seem many transformations since the first handicraft wool pieces and the first tents until the present. As a result, it is remarkable the diversification of handicraft products and how the commercial trades changed over time, reconfiguring this rural community. This transformations were made mainly by the necessity to supply and to attract a consumer market relating handicraft, identity and income growth.
\end{abstract}

Keywords: craftsmen; rural community; symbolic market; traditional knowledge; tents

\footnotetext{
Universidade Federal de Santa Maria, RS, Brasil - https://orcid.org/0000-0002-6356-3594 - helenabeling2015@gmail.com

" Universidade Federal de Santa Maria, RS, Brasil - https://orcid.org/0000-0002-5244-811X - dreissefantineli@gmail.com

I'I Universidade Federal de Santa Maria, RS, Brasil - https://orcid.org/0000-0002-4850-5492 - janetewc@gmail.com

Iv Universidade Federal do Recôncavo da Bahia, BA, Brasil - https://orcid.org/0000-0003-4341-0264 - loretodevargas@gmail.com 


\section{INTRODUÇÃO}

A presente pesquisa trata de um estudo de caso sobre o artesanato e a geração de renda dos artesãos da comunidade rural da Vila Progresso, localizada no município de Caçapava do Sul, metade sul do Rio Grande do Sul (RS). Conhecida também como região do Pampa Gaúcho. Sendo esta, uma forma de resistência para manter as tradições, a memória, e os saberes tradicionais, preservando assim, a identidade dos sujeitos e, ao mesmo tempo, gerando uma alternativa de desenvolvimento econômico para a comunidade. Na localidade o saber-fazer relacionado às peças do vestuário de característica rústica e os utensílios utilizados para o trabalho no campo, foram reinterpretadas para o presente e a estas dadas novas conotações. Estas são características relevantes para os produtos confeccionados, pois são atribuídas as simbologias históricas e culturais do gaúcho, a partir da interpretação do seu modo de vida no campo (OLIVEN, 1998; 2006).

O território do Pampa, em termos de biodiversidade natural, configura-se como um dos seis biomas terrestres ou grandes regiões naturais do Brasil. É o único que se estende por um só estado, representando 63\% do território gaúcho e 2,1\% do território nacional (BENCKE, CHOMENKO, SANT'ANNA, 2016). Onde os aspectos culturais são vastos, turismo, artesanato e mercado simbólico estão permeados por um contexto onde cultura, memória, saberes e fazeres se entrelaçam com as paisagens e a biodiversidade do território, justificando as práticas culturais e os saberes tradicionais que se concretizam, por vezes, no fazer artesanal de produtos em couro, lã e madeira típicos da biodiversidade do território.

O produto confeccionado artesanalmente, geralmente, representa um resgate das memórias e uma manutenção da cultura das comunidades, tendo em vista a presença dos simbolismos e das histórias de vidas nas peças confeccionadas pelos artesãos. Para Vives (1983, p. 135), tal fato se refere à manutenção de uma identidade, com características funcionais e de embelezamento. Nesse sentido, o artesanato é a “[...] reafirmação das necessidades básicas do ser humano, que, na verdade, o conduzem a 
identificar-se, a rever-se não só como um ser capaz de múltiplos afazeres, mas como pessoa "pertencente" - não desenraizada, antes incluída num sistema próprio e seu".

Na visão de Canclini (1983, p. 91), “[...] o artesanato é um lugar privilegiado para se perceber a rapidez e a multiplicidade de modificações que o capitalismo introduz nas culturas tradicionais". Reflexão que culmina com a visão de Santos (2006, p. 124), quando autor destaca que no início existiam “[...] múltiplas equações técnicas, numerosas formas de utilização e criação de recursos. As escolhas eram várias. À medida que o capitalismo se desenvolve, diminui o número de modelos técnicos, a escolha se torna mais estreita".

Estudos como este, justificam-se no sentido de demonstrar ao mundo acadêmico que os aspectos culturais de algumas comunidades rurais continuam vivos, mesmo diante de um mundo globalizado, onde a cultura parece cada vez mais global e menos e territorial. Nesse sentido, Neto e Bezzi (2009, p. 21) afirmam que é importante ressaltar que “[...] À medida que se prega a homogeneização dos espaços no Globo, tem-se afirmado, cada vez mais, as diferenças, ou seja, o local e o regional, os quais ainda guardam as suas respectivas identidades". E ainda, apontam que: “[...] de maneira geral, os atuais debates relativos à questão cultural discutem as implicações do processo de globalização na cultura e na identidade, principalmente, quanto a sua homogeneização ou a afirmação da diversidade" (Neto; Bezzi, 2009, p. 22).

No contexto do processo atual da globalização, Santos (2006, p. 27) afirma que existe desejo do "[...] domínio do mundo na associação entre grandes organizações e uma tecnologia cegamente utilizada. Mas a realidade dos territórios e as contingências do "meio associado" asseguram a impossibilidade da desejada homogeneização". Oliven (2006, p. 208) ressalta que, todo o processo de mundialização da cultura que dá a sensação que vivemos em uma “[...] aldeia global, acaba repondo algumas questões da tradição, da nação e da região. À medida que o mundo torna-se mais complexo e se internacionaliza, a questão das diferenças se recoloca e há um intenso processo de construção de identidades". 
Nessa perspectiva, conforme destaca Neto e Bezzi (2009, p. 20) a identidade tornou-se um meio de valorização, do espaço como forma de dinamizar a economia “[...] Em um mundo globalizado, a cultura tem se constituído no diferencial, que resulta em atrativo socioeconômico e possibilita, muitas vezes, uma perspectiva de desenvolvimento".

Nesse sentido, o objetivo desse estudo de caso, configura-se em compreender qual a contribuição do artesanato para a construção da identidade cultural, bem como, para a geração de renda no contexto da comunidade rural da Vila Progresso, Caçapava do Sul/RS.

A escolha pela comunidade rural de Vila Progresso, em Caçapava do Sul/RS, se justifica pela presença dos artesãos que realizam suas atividades embasadas em saberes tradicionais. Durante a visita e o diálogo estabelecido, na pesquisa de campo realizada, conhecemos artesãos e suas tendas de artesanato, destacando, desse modo, os aspectos sociais, culturais e econômicos, enfatizando as transformações e resistências, bem como, a importância de conservar e valorizar sua cultura e identidade. Assim, conforme Neto e Bezzi (2009, p. 20), individualizar recortes espaciais culturais acarreta em uma "[...] uma estreita relação entre espaço-cultura e códigos culturais, da qual resulta a identidade não somente do grupo social, mas também da sua base espacial, os quais são indissociáveis, uma vez que o homem necessita do substrato territorial".

Para atender o objetivo proposto, o trabalho foi estruturado, a partir dessa parte introdutória, em uma seção que apresenta os procedimentos metodológicos e a caracterização da área de estudo. Em seguida, abordamos o artesanato como busca e preservação da identidade, trazendo aspectos da geografia cultural; posteriormente o artesanato como geração de renda; na sequência, desenvolvemos o contexto da Vila Progresso, destacando o artesanato, a cultura, a identidade e a renda. Por fim, algumas considerações finais.

\section{PROCEDIMENTOS METODOLÓGICOS}

Para atingir os objetivos propostos nesta investigação utilizaremos a perspectiva da pesquisa qualitativa. De acordo com Matos e Pessôa (2009, p. 279), a pesquisa 
qualitativa é diferente da quantitativa devido às questões teórico-metodológicas. Pois, “[...] Enquanto a pesquisa quantitativa procura estabelecer e seguir um plano elaborado com rigidez, os estudos qualitativos costumam ser direcionados ao longo do seu desenvolvimento". Sendo que, a coleta de dados, que acontece ao longo da pesquisa, é constituída para a interpretação do fenômeno estudado.

Completando a ideia das autoras, Goldenberg (2004, p. 14) afirma que nestas pesquisas o pensamento do pesquisador não é com a representação em números dos grupos pesquisados “[...] mas com o aprofundamento da compreensão de um grupo social, de uma organização, de uma instituição, de uma trajetória etc".

Nesse sentido, com o intuito de compreender a realidade da investigação, para a obtenção de informações e dados para a pesquisa, utilizamos os seguintes procedimentos, técnicas e instrumentos: pesquisa bibliográfica, trabalho de campo, observação, entrevistas, diário de campo e registros fotográficos. Devido à necessidade de reunir informações sobre a área de estudo e o tema em questão, este trabalho apresenta os procedimentos e as técnicas metodológicas divididos em três fases.

A primeira fase foi constituída da pesquisa teórica. Esta fase teve o intuito de fornecer discussões teóricas que possibilitassem a compreensão do fenômeno pesquisado, bem como auxiliar na compreensão da realidade da área pesquisada.

A segunda fase da pesquisa, contou com a realização do trabalho de campo, no ano de 2018, para a coleta dos dados, junto aos artesãos da comunidade rural da Vila Progresso. Ao tratar da realização do trabalho de campo, sobretudo em Geografia Humana, Hespanhol (2015, p. 53) afirma que “[...] envolve uma maior relação de proximidade entre o pesquisador e o pesquisado [...]" ressalta a importância do respeito. Visto que, na relação pesquisador e pesquisado, é necessário algumas habilidades, como: "saber ouvir; valorizar o modo de vida, a cultura, os valores e a opinião do outro; etc". Ao concluir a relevância do trabalho de campo para a pesquisa Hespanhol (2015, p. 55), afirma que é um momento extremamente importante para “[...] apreensão de aspectos, fenômenos e/ou processos manifestados espacialmente 
numa dada localidade e, sobretudo, de convívio e de trocas de experiências e de informações com as pessoas da localidade abarcada".

No primeiro momento do trabalho de campo, realizamos o reconhecimento e a caracterização dos artesãos desta comunidade rural, levando em consideração as suas características culturais, sociais, econômicas. Nesse momento identificamos 16 artesãos, dos quais, nove foram pesquisados. Os nove artesãos entrevistados foram indicados por um informante qualificado, que é artesão, morador e presidente da associação de moradores da comunidade rural de Vila Progresso. A escolha dos depoentes foi orientada pelo morador da comunidade, que, também, guiou e auxiliou a realização do trabalho de campo, buscando informantes qualificados para mostrar a história, a diversidade, as transformações, o conhecimento e a experiência no que tange a produção do artesanato da comunidade em questão. Com o trabalho de campo foi possível perceber in loco a temática em trabalhada.

A coleta de dados junto aos artesãos ocorreu com a ajuda de alguns instrumentos de pesquisa: roteiro de entrevista semiestruturado, técnica da observação, registros fotográficos e diário de campo.

A entrevista semiestruturada é recomendada porque permite informações além das previstas. Elas “[...] se constituem na interação entre perguntas abertas e fechadas (previamente formuladas), em que o informante tem a possibilidade de discorrer sobre o assunto proposto de forma mais espontânea" (MATOS; PESSÔA, 2009, p. 288). Esta técnica de coleta de dados respeita as questões levantadas como importantes por parte do pesquisado, muitas vezes destacando detalhes que passariam despercebidos ou trazendo novos elementos, respeitando a conversa entre o pesquisador e o pesquisado.

Na técnica da observação, utilizamos a observação sistemática, que também recebe as designação de estruturada, planejada e controlada, realizada com o intuito de coletar dados e fenômenos que dão suporte para atender aos objetivos da pesquisa. E, a observação não-participante, onde não há interação com as atividades desenvolvidas com os artesão, nesse tipo de observação não há envolvimento com as situações, o observador apenas analisa (MARKONI; LAKATOS, 2003). 
Já o uso dos registros fotográficos foi importante para o desenvolvimento desta pesquisa, pois ilustrou as análises da pesquisa e mostrar a realidade mais concreta, sendo uma representação do espaço estudado. Ao abordar a utilização de fotografias Ramos e Pessôa (2017, p. 456) destacam que "[...] é para contribuir na percepção, na ilustração e na documentação dos fenômenos investigados. Representa o pensamento do fotógrafo ou uma forma de expressão de um espaço, aquilo que se queira dizer [...]".

O registro de dados no diário de campo, Marafon (2009, p. 389) salienta que “[...] é mais que um simples registro de fatos, ele reflete a memória do pesquisador para que as informações sejam analisadas em profundidade". Dessa forma, facilita à escrita e a reflexão, pois o diário de campo é usado para fazer anotações, descrever percepções e fatos que observados durante a realização do trabalho de campo. Assim, "[...] Este instrumento faz com que observemos o espaço de uma forma mais atenta. São gestos, emoções, histórias, lugares registrados no papel que, ao serem lidos e relidos, nos permitem voltar na mente o trajeto da pesquisa de campo" (RAMOS; PESSÔA, 2017, p. 454). As anotações realizadas no diário de campo foram à base para a análise e discussões dos resultados abarcados com a pesquisa na comunidade da Vila Progresso.

Por fim, a terceira fase se caracterizou pelo cruzamento dos dados e das informações pesquisadas, a partir do qual, tornou-se possível apresentar tal discussão. Fazendo assim, a organização, sistematização e a tabulação das informações e dos dados coletados, possibilitando análise específica da área e do tema da pesquisa. A utilização conjunta dos instrumentos metodológicos possibilitou compreender a importância do artesanato para a geração de renda dos artesãos da comunidade rural de Vila Progresso.

\section{CARACTERIZAÇÃO DA ÁREA DE ESTUDO}

O município de Caçapava do Sul está localizado na metade sul do RS, conhecida, também, como região do Pampa Gaúcho. Os campos do Bioma Pampa, estendem-se entre o Uruguai, Argentina e Brasil. O Pampa, no Brasil, tem área aproximada de 
$176.496 \mathrm{Km}^{2}$, correspondendo a 2,07\% da área total do país, se restringe ao estado do RS onde ocupa 63\% do território (IBGE, 2004). “[...] Essa região, denominada Pastizales del Río de la Plata ou, simplesmente, Campos e Pampas, constitui a maior extensão de ecossistemas campestres de clima temperado do continente sul-americano" (BENCKE; CHOMENKO; SANT'ANNA, 2016, p. 17).

Passou-se a reconhecer o Pampa como uma delimitação geográfica específica a partir do mapa do Instituto Brasileiro de Geografia e Estatística (IBGE) de 2004 (IBGE, 2004). Até então, parte do Pampa era tratado como Mata Atlântica.

As paisagens naturais do Pampa são variadas, de serras a planícies, de morros rupestres a coxilhas. O bioma exibe um imenso patrimônio cultural associado à biodiversidade. As paisagens naturais do Pampa se caracterizam pelo predomínio dos campos nativos, mas há também a presença de matas ciliares, matas de encosta, matas de pau-ferro, formações arbustivas, butiazais, banhados, afloramentos rochosos, etc (MMA, 2019).

O Pampa é um conjunto de ecossistemas muito antigos, abriga flora e fauna próprias e com grande biodiversidade. "Trata-se de um patrimônio natural, genético e cultural de importância nacional e global. Também é no Pampa que fica a maior parte do aquífero Guarani". A pecuária extensiva, sobre os campos nativos, tem sido a principal atividade econômica, trazendo resultados econômicos importantes e permitido a conservação da cultura (MMA, 2019).

São necessárias atividades que garantam a conservação do Bioma Pampa, onde o desenvolvimento econômico e social garanta a sustentabilidade. Sendo preciso “[...] A diversificação da produção rural a valorização da pecuária com manejo do campo nativo, juntamente com o planejamento regional, o zoneamento ecológico-econômico e o respeito aos limites ecossistêmicos" (MMA, 2019). Haja vista que, não é suficiente apresentar o “[...] Pampa apenas como um espaço natural, de paisagem, vegetação e biodiversidade típicas. Qualquer definição que se pretenda dar a essa região será 
incompleta se não considerar a dimensão sociocultural" (BENCKE; CHOMENKO; SANT'ANNA, 2016, p. 19).

Neste contexto, está inserido o município de Caçapava do Sul/RS, objeto deste estudo. Este município possui uma população, conforme o censo do IBGE do ano de 2010, de 33.690 pessoas, com área de unidade territorial total de $3.047,11 \mathrm{~km}^{2}$, e densidade demográfica de 11,06 hab/ $\mathrm{km}^{2}$. A população estimada para o ano de 2019 é de 33.624 pessoas. Seus municípios limítrofes são: São Sepé, Cachoeira do Sul, Santana da Boa Vista, Pinheiro Machado, Bagé e Lavras do Sul (IBGE, 2017), conforme pode ser observado na figura 1.

Figura 1 - Localização da área de estudo

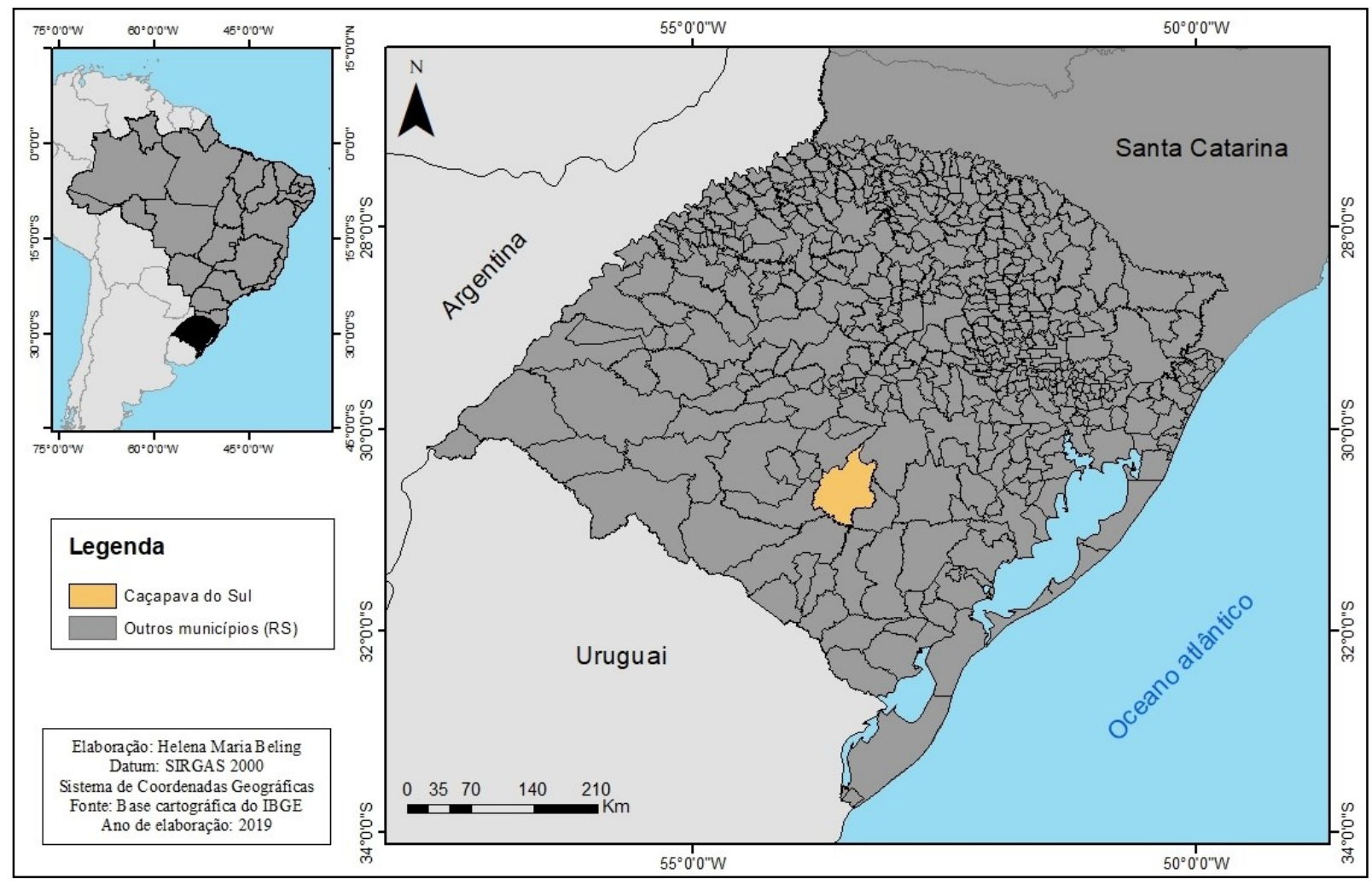

Fonte: IBGE (2018)

Organização: BELING, H. M (2019)

É um dos municípios mais antigos do estado, sendo considerada a segunda Capital Farroupilha. Caçapava do Sul está localizada no sudeste do estado do Rio Grande do Sul. O município fica a $250 \mathrm{~km}$ da capital do RS, Porto Alegre, sua economia é 
basicamente sustentada pela Mineração, Agricultura e Pecuária (PREFEITURA DE CAÇAPAVA DO SUL, s/d).

A localização geográfica de Caçapava do Sul/RS está entre os fatores que possibilitam a continuidade e permanência dos artesãos ao longo dos anos. O município é cortado por várias vias, sendo elas: BR - 392 que faz a ligação norte-sul, liga a Região das Missões ao porto de Rio Grande; a BR - 290 que é no sentido lesteoeste, liga Uruguaiana a Porto Alegre; a BR - 153, que liga a BR - 290 à cidade de Bagé. Nesse sentido, o município é privilegiando com suas rotas, visto que, possui uma entrada via Uruguai e outra via Argentina, tornando-se rota obrigatória nos caminhos do Mercado Comum do Sul (Mercosul) (PREFEITURA DE CAÇAPAVA DO SUL, s/d). Essas rotas possibilitam intenso fluxo de caminhoneiros e turistas, o que viabiliza a comercialização do artesanato.

A comunidade rural de artesão da Vila Progresso é uma das mais dinâmicas do município e surgiu por iniciativa de mulheres, as quais vislumbravam no artesanato uma possível fonte de renda, pela facilidade de comercialização dos produtos nas proximidades da BR-290. No início os produtos confeccionados eram, sobretudo, produtos em lã, como ponchos e palas (DIÁRIO DE CAMPO, 2018).

No local residem, aproximadamente, 68 famílias que são formadas por pequenos proprietários, os mesmos possuem, aproximadamente, 1,5 hectares de terra nesta comunidade (VARGAS, 2016). Algumas famílias possuem outras áreas de terra localizadas nas proximidades, onde criam animais e cultivam produtos agrícolas para o autoconsumo. Também existem casos de famílias que arrendam suas propriedades para o plantio de soja e arroz e/ou criação de pecuária de gado (DIÁRIO DE CAMPO, 2018). Nesse sentido “[...] não dá para vê-las separadas na vida do pequeno agricultor familiar [...]" (TEDESCO, 2010, p. 144).

A Vila Progresso localiza-se às margens da BR-290, distante, aproximadamente 25 km da cidade, possui posto de saúde, agente comunitário de saúde, luz elétrica, água encanada de postos artesianosi, coleta de lixo e associação de moradores, escolaii, igrejas (católica e evangélica), salão de festas, supermercado, agropecuária, casa de 
mel, indústria de azeite de olivaiii, loja de material de construção. Importante ressaltar que a economia da localidade gira em torno da produção e comercialização dos produtos artesanais, especialmente artigos em lã. Nesse sentido a comunidade também tem se organizado para receber turistas que procuram a região para comprar peças artesanais. Grande parte dos artesãos está na comunidade há mais de três décadas (DIÁRIO DE CAMPO, 2018; VARGAS, 2016).

Salientamos que, a indústria de azeite de oliva gera empregos diretos na comunidade, sendo este o único estabelecimento não familiar da Vila Progresso. Haja vista que, os demais têm por característica a mão de obra e a administração familiar, gerando alguns empregos temporários, conforme necessidade. Também destacamos a significativa quantidade de aposentados que residem na comunidade, grande parte deles desenvolvem atividades ligadas ao artesanato. Os homens que não trabalham com o artesanato, desenvolvem atividades agropecuárias no município ou em municípios próximos; e as mulheres da comunidade que não trabalham com o artesanato, desenvolvem atividades de domésticas e/ou diaristas na própria comunidade ou na área urbana do município (DIÁRIO DE CAMPO, 2018; VARGAS, 2016).

\section{O ARTESANATO COMO BUSCA E PRESERVAÇÃO DA IDENTIDADE CULTURAL}

A cultura é fundamental na investigação da relação do homem com a natureza. A geografia cultural estuda as inúmeras manifestações culturais com suas identidades culturais. Assim, entende como as inúmeras manifestações culturais são caracterizadas e delimitadoras nas esferas geográficas.

Nas palavras de Bezzi (2009, p. 15), o fenômeno cultural “[...] é vivenciado pelo grupo e se expressa no território que ele ocupa, servindo, portanto, como inspirador e parâmetro das formas de organização social. Através da identidade cultural, um grupo social de identifica e é reconhecido pelos demais". Neste entendimento, esta pesquisa teve como área de estudo a comunidade rural de Vila Progresso, Caçapava do Sul/RS. 
Ao falar da atenção dos objetos de investigação dos estudos de cultura pelos geógrafos, Corrêa (2009, p. 5) aponta que devido à abordagem da realidade, a interpretação dos pensamentos e das práticas do outros grupos sociais, “[...] a geografia cultural não é definida por um objeto específico, como a própria cultura, concebida segundo o senso comum ou segundo uma visão abrangente".

Os aspectos culturais são fundamentais para orientar as relações no espaço, com diferentes características e particulares de determinados grupos sociais. Haja vista que “[...] a cultura atribui significado a tudo, desde sons vocais deliberadamente articulados até seres, objetos e lugares" (WAGNER; MIKESELL, 2003, p. 29).

A cultura transmite ensinamentos, que mostra as particularidades e especificidades dos diferentes grupos sociais, tanto no que diz respeito aos aspectos materiais quanto aos imateriais. Conforme Corrêa (2009, p. 2) “A produção e reprodução da vida material é medida na consciência sustentada pela produção língua, gestos, costumes, rituais, artes, a concepções da paisagem, etc". Completando essa ideia Congrove (2003, p. 103) afirma que “[...] toda atividade humana é, ao mesmo tempo, material e simbólica, produção e comunicação".

Contudo, a cultura é a chave da significação entre a materialidade do espaço e as características da existência e consciência social. Podem ser considerados tanto a dimensão material da cultura como sua dimensão não-material, o presente e como o passado, os objetos e as ações, os aspectos e os intersubjetivos. Na Geografia Cultural esses aspectos são vistos em termos de significados e como parte integrante da espacialidade humana (CORRÊA; ROSENDAHL, 2003).

Assim, a produção e reprodução de vida material é uma arte coletiva, produzida com consciência e amparada por códigos de comunicação (produção simbólica). Os códigos são a linguagem formal, além do gesto, vestuário, conduta pessoal e social, música, pintura, dança, ritual, cerimônia e as construções. O uso dos códigos produzem estilos de vida e paisagens diferentes. Nesse sentido, a geografia cultural apreende e compreende essa dimensão da interação humana com a natureza, bem como, o seu papel na ordenação do espaço (COSGROVE, 1998). 
Nessa acepção, a cultura relaciona o presente e o passado com outros grupos sociais e culturas. Conforme Bezzi (2009, p. 16) “[...] é através do estudo dos costumes, dos hábitos que se pode interpretar um determinado grupo social e perceber as disparidades regionais, que orientam as análises espaciais do desenvolvimento". Cosgrove (1998) reforça a importância da cultura como organizadora do espaço, responsável pela identificação dos grupos sociais. Nesse sentido, é importante considerar que:

A cultura aparece como um conjunto de gestos, práticas, comportamentos, técnicas, conhecimentos, regras, normas e valores herdados dos pais e da vizinhança, e adaptados através da experiência a realidade sempre mutáveis. A cultura é herança e experiência. Ela é também projeção em direção ao futuro. Os outros mundos dos alhures permitem julgar o presente e pensar o futuro: eles dão aos seres humanos o poder de julgar o real, de discernir entre o bem e mal, de fazer escolhas e tomar decisões conforme as regras morais. Mas cada um constrói, a partir das visões morais que a sociedade lhe oferece, e da sua experiência, horizontes futuros. Graças a esses horizontes, a cultura aparece mais como a força que dá a sua forma ao futuro que como a repetição do passado (CLAVAL, 2007, p. 163).

A essência cultural das atitudes e ações de um determinado grupo social se materializa no espaço, por meio de códigos específicos. As simbologias são representadas nas formas, com significados próprios. Os códigos são responsáveis pela visibilidade da cultura, bem como, pela transmissão, que são impressos nas diferentes paisagens (Cosgrove, 1998).

Para Haesbaert (2004) a construção dos símbolos e das identidades culturais passa por uma relação, muitas vezes produzidas por processos culturais híbridos, já que os sujeitos são dinâmicos, se deslocam e passam por variados tipos de influências, sejam em termos geo-históricos e/ou socioculturais. Essa dinâmica enfatiza a sua dimensão simbólico-identitária. 
O valor simbólico é atribuído às peças artesanais quando elas se remetem a fatos, expressões, memórias e tradições, tanto para as pessoas que as confeccionam quanto para aos consumidores (BOURDIEU, 1989). O simbolismo representado pela peça artesanal, no momento que é acionado pelo imaginário das pessoas, faz menção a sentidos de uma tradição do passado para o tempo presente, em que novos valores e significados podem ser atribuídos (TEDESCO, 2013).

Para entender as transformações e reorganização do espaço, é de suma importância entender a relação da sociedade e natureza mediada pela técnica. Levando em conta a complexidade do processo de globalização que gera consideráveis “[...] transformações socioeconômicas e culturais em escala local, regional e global e, principalmente, coloca em evidência as diferenças. Tal situação origina as identidades regionais, pautadas em uma simbologia típica inerente a um determinado grupo social". Nos debates atuais da globalização, considera-se que "[...] ocorre a homogeneização dos costumes. Entretanto, o que se observa, recentemente, é um movimento inverso, que se caracteriza pela intensa reivindicação de identidades, como forma de procurar diferenciar-se desse padrão homogêneo" (NETO; BEZZI, 2009, p. 22).

Pode-se dizer, então, que, a globalização desencadeou um movimento de reconhecimento identitário, que representa uma releitura cultural, onde os grupos sociais se reafirmam mediante laços simbólicos com os seus semelhantes e com o espaço em que vivem. Os membros de um mesmo grupo cultural tendem a seguir um sistema simbólico de crenças e valores que guiam suas atitudes, como uma espécie de "código de conduta" subjetivo e interno à legislação do Estado. Todo esse sistema simbólico se materializa no espaço, tornando-o distinto dos demais, originando a identidade do grupo cultural, através de traços típicos inerentes a determinada cultura.

A identidade cultural configura-se, então, como fator essencial para a manutenção cultural à medida que se afirma e é valorizada, tornando-se mais resistente às influências externas. Por conseguinte, a cultura é o contraponto da tendência à homogeneização, via diversidade étnica existente no globo (NETO; BEZZI, 2009, p. 22). 
No contexto do RS, uma característica expressiva atribuída ao gaúcho é a simbologia histórica e cultural, por meio da interpretação do seu modo de vida no campo (OLIVEN, 2006). Sobretudo, na região do Pampa Gaúcho, as simbologias tradicionais, como por exemplo, as peças do vestuário que possuem característica rústica e os utensílios utilizados na realização do trabalho no campo foram reinterpretadas para o presente e a atribuídas novas significações e usos (VARGAS, 2016). Essa reinterpretação tem efeito nos produtos artesanais, e com isso, o público consumidor se ampliou de maneira significativa.

Na visão de Neto e Bezzi (2009, p. 25) “[...] a cultura se configura, atualmente, no Rio Grande do Sul como um agente eficaz para alicerçar o desenvolvimento socioeconômico das distintas porções do espaço gaúcho, através das peculiaridades implícitas a cada sistema de codificação cultural". Em torno da relação entre a produção agrícola e não agrícola artesanal, com patrimônios culturais e estratégias de reprodução de pequenas unidades familiares. Há relação “[...] entre fenômenos tradicionais e culturais com as dinâmicas mercantis modernas, com os canais do turismo territorializados e etnicizados, em dinâmicas mercantis que denotam esferas de proximidade, de saberes e aprendizagens coletivas em esferas locais" (TEDESCO, 2010, p, 136).

Alguns dos produtos artesanais mais característicos do RS são de hábitos adquiridos no Pampa Gaúcho, com forte influência da cultura indígena. Dentre os elementos simbólicos do gaúcho no mercado, os artigos, artesanalmente, produzidos em lã, couro e madeira têm significativa importância, como os utensílios para as casas, trabalhos realizados no campo e agasalhos para o frio (VARGAS, 2016). Entretanto, o mercado dos produtos gauchescos sempre existiu, porém, com o tempo formou novas dinâmicas com aumento considerável, sendo o mercado simbólico.

Ao falar dos discursos acerca do artesanato, Lima (2005, p. 13) afirma que, atualmente, no Brasil, entre os vários segmentos que lidam com a produção artesanal, assim, estabeleceu-se um debate capaz de refletir essa questão. Nesse sentido: 
De um lado está o discurso que preconiza a conservação do objeto nas condições em que foi produzido, por entender que ele é testemunho de um passado a ser preservado. Geralmente associado aos segmentos de baixa renda ou populares da sociedade, de acordo com essa visão, o objeto artesanal seria dotado de uma estética perfeita que refletiria o gosto de seu produtor. De outro lado encontra-se um discurso que advoga a adequação do artesanato aos "tempos contemporâneos", que preconiza a transformação de sua forma, a criação de um novo design, "refinado", como condição para garantir o mercado.

O artesanato tradicional, encontrado na referida comunidade rural de Vila Progresso, conta com saberes e práticas culturais tradicionais, nas peças produzidas ficam materializadas seus valores coletivos e identidades culturais. $O$ artesão tradicional conforme Vives (1983, p. 133) é “[...] aquele que emprega e transmite, em seu trabalho, valores, técnicas e signos amadurecidos e aceitos no sistema cultural a que ele mesmo pertence". Indo ao encontro com a ideia da autora, Lima $(2005$, p. 14) se refere ao artesanato tradicional ou de raiz como “[...] Um tipo de objeto que traz em si a expressão de sua própria origem, que traz condensada em si a marca forte da cultura; um objeto capaz de traduzir uma identidade, sua e daquele que o produziu, seja um indivíduo ou uma coletividade".

Os produtos confeccionados pelos artesãos assumem papel de identidade para determinado grupo. A partir do conceito proposto pelo Conselho Mundial do Artesanato (WWC, s/d), define-se como artesanato toda atividade produtiva que resulte em objetos e artefatos acabados, feitos manualmente ou com a utilização de meios tradicionais ou rudimentares, com habilidade, destreza, qualidade e criatividade.

Existe, atualmente, uma grande demanda por produtos artesanais. Fato este que acorre, principalmente, por esses produtos remeteram a identidade e ao pertencimento. É a cultura de um povo que por muitas vezes une um grupo de pessoas, pois estas geralmente buscam preservar sua identidade. Complementando essa ideia, nas palavras de Neto e Bezzi (2009, p. 20) “[...] a identidade cultural é indispensável para a manutenção de um grupo social e, também, para o entendimento da produção do 
espaço local e regional em seus respectivos níveis de desenvolvimento". Caetano (2012, p. 54) sobre identidade, fala que,

Portanto, a formação de identidades sólidas requer a relação estreita com a cultura e os símbolos mais representativos da mesma. Convém lembrar que a identidade pressupõe um limite, ou seja, considera os atributos semelhantes de um mesmo grupo social e delimita o mesmo ao evidenciar as diferenças culturais de um outro grupo. Enfatiza-se, por isso, a existência de uma identidade individual, pautada nas experiências de cada sujeito, porém, exalta-se a identidade cultural como um conjunto de marcas culturais que norteiam a conduta dos indivíduos pertencentes à uma mesma cultura.

São essas marcas culturais, identificados como símbolos culturais que vão remeter as pessoas a sua identidade. E essa identidade pode ser preservada através das músicas, das danças, da gastronomia, dos artigos artesanais, dentre outros.

\section{O ARTESANATO COMO GERAÇÃO DE RENDA}

A valorização do artesanato está atrelada ao valor simbólico que o mesmo possui. Atribui-se um valor simbólico as peças artesanais no momento em que as mesmas conseguem comunicar fatos, expressões, memórias e tradições, seja para aqueles que as confeccionam e/ou para aqueles que as adquirem (BOURDIEU, 1989). O simbolismo que a peça artesanal representa, ao ser acionado pelo imaginário das pessoas, transporta sentidos de uma tradição do passado para o tempo presente, onde novos valores e significados podem Ihe ser atribuídos (TEDESCO, 2013).

Esse sentimento de pertencimento da população local, na maioria das vezes, é o que contribui para darem continuidade na produção de um tipo de artesanato. A partir desta prática conseguem manter presente a tradição da família, a memória oriunda de seus antepassados é preservada e reproduzida nas peças do artesanato. Nesse sentido, Vives (1983, p. 133) destaca que “compreendemos como artesão tradicional aquele que emprega 
e transmite, em seu trabalho, valores, técnicas e signos amadurecidos e aceitos no sistema cultural a que ele mesmo pertence". Nas palavras de Mello (2015, p. 107),

O discurso de valorização do artesanato vai ao encontro das noções atuais de desenvolvimento territorial que entendem ser preciso levar em consideração os aspectos culturais e simbólicos do território para obter um desenvolvimento endógeno, de baixo para cima, que atenda às reais necessidades da comunidade em questão. Entende-se que a valorização do artesanato tradicional rural fortalece o sentimento de pertencimento da população ao local, facilitando ações que visem ao seu desenvolvimento.

Existem vários tipos de turistas que compram artesanatos, tanto nas cidades turísticas, quanto na beira das estradas, entre outros lugares. Para Arruda et. al (2013, p. 663),

Basicamente, existem dois principais grupos de turistas ou de
'olhar turístico'. O primeiro deles nasce da presença de um grande
número de pessoas, e tem um sentido carnavalesco e um caráter
cosmopolita e homogêneo; é o padrão encontrado no turismo de
massa, em que há oferta padronizada, restringindo a
oportunidade de escolha de consumidor. O segundo tipo de olhar
equivale ao romântico, um relacionamento espiritual e pessoal
como objeto turístico. É representado por produtos cada vez mais
segmentados, a fim de atingir variadas motivações e padrões de
compra.

Entende-se que esse olhar romântico, espiritual, está mais ligado aos sujeitos que buscam num produto uma relação de identidade, que remonte a sua vivência em algum período da vida. No mundo de hoje, em que muitos costumes e tradições estão se perdendo, as pessoas procuram formas de manter vivas suas lembranças de infância, as suas características, entre outras. Essa identidade muitas vezes pode estar atrelada a um simples objeto, porém, se torna uma peça de grande valor sentimental, que remete a uma cultura. Esse é o caso da comunidade rural da Vila Progresso, localizada em Caçapava do Sul/RS, que conta com produção e comercialização de 
produtos artesanais. A referida comunidade possui fortes elementos históricos, que oportunizam a região na prática e no saber do artesanato tradicional.

Em um contexto geral, para o artesanato em áreas rurais, a produção das peças e a comercialização ficam a cargo da mulher, e o homem é responsável por outra atividade, geralmente a agricultura, pecuária. Essa relação de trabalho não é homogênea, a inserção tanto da mulher quanto do homem no artesanato está diretamente relacionada a função econômica que o artesanato representa para a família. Nos espaços em que a principal fonte de renda provém do artesanato a inserção do homem é constante.

Nessa perspectiva, conforme Tedesco (2010, p. 144), algumas mulheres, como é o caso das artesãs da Vila Progresso, encontraram na diversificação, em forma de artesanato, uma alternativa para permanecer no meio rural, subsidiar as atividades agrícolas mais tradicionais e evitar o assalariamento urbano e mudança de vida. E assim, uma maneira de renda e trabalho "[...] com a intenção também de fazer com que filhos permaneçam na unidade familiar; agrega fatores sinérgicos às atividades agrícolas que, no meio rural de famílias mais tradicionais, tendem a se reproduzir [...]".

Ações como estas criam alternativas de trabalho e renda no meio rural, onde as famílias com poucos recursos econômicos e pequena área de terra, fazem uso de seus saberes para construir uma alternativa rentável e assim conseguirem manter-se no meio rural (CANCLINI, 1983). O início da comercialização e a diversificação de produtos artesanais na comunidade da Vila Progresso propiciou um processo de desenvolvimento econômico, ampliando população do local e a geração de empregos, o que por fim, também possibilita uma melhor organização estrutural da comunidade.

Cabe salientar que, o artesanato não é somente mercadoria, na medida em que ele possui valores, crenças, culturas e identidade. Nesse sentido, Lima (2005, p. 16) aponta em um objeto/produto do artesanato “[...] é capaz de conter em si uma série de valores, de crenças, de costumes que fazem o seu diferencial". Neste contexto entre preservar e produzir para o mercado consumidor, Leite (2005, p. 32) contextualiza que: 
Se o dilema da visão tradicionalista é como manter o artesanato, mesmo que mudem os modos de vida, o dilema da visão mercadológica é como alterar o artesanato, adaptando-o às exigências do mercado, mesmo que não sejam modificados os modos de vida. Uma perspectiva puramente mercadológica, portanto, esbarra nos limites dos contextos sociais da produção artesanal.

Uma característica importante da produção artesanal é a família, que, em grande parte, tem conhecimento integral do processo de produção. Sendo essa uma das “[...] mais antigas e importantes características da produção artesanal, em diferenciação à produção manufatureira e industrial. Podemos dizer que é típico da produção artesanal o conhecimento, por parte do artesão, de todas as etapas constitutivas da produção".

O saber e o fazer andam juntos (LEITE, 2005, p. 36). Nesse sentido, é preciso entender o artesanato nas relações de mercado como "[...] um produto diferenciado; que nunca se perca a dimensão cultural que está embutida nele, porque quando se lida com a cultura, se agrega valor, e assim se consegue fazer com que o objeto seja mais valorizado e mais caro exatamente por essa razão" (LIMA, 2005, p. 17).

$\mathrm{Na}$ área pesquisada constata-se que vários são os produtos produzidos e comercializados no local. Grande parte destes artigos são produtos fabricados em lã, couro e madeira. Os artigos em lã são produtos presentes em todas as tendas, são os itens mais tradicionais, confeccionados e comercializados pelos artesãos da comunidade.

\section{VILA PROGRESSO: IDENTIDADE, CULTURA E GERAÇÃO DE RENDA}

Há um pouco mais de três décadas deu-se a instalação das primeiras artesãs na comunidade (VARGAS, 2016). Com a realização do trabalho de campo percebemos que, além do artesanato, as famílias de algumas tendas também exercem atividades concomitantes, como a produção agrícola. São produzidos vários produtos como é o 
caso de frutas, hortaliças, mandioca, batata, também há criação de galinhas, gado e ovelhas (DIÁRIO DE CAMPO, 2018).

Esses alimentos garantem o autoconsumo das famílias da comunidade, alguns produtos, excedentes, são comercializados nas tendas, pontos de comercialização dos artigos artesanais. Especialmente as mulheres agricultores do local, dedicam-se a fazer doces e geleias para comercialização, visando uma maior diversidade de produtos para atrair os turistas. Outras mulheres da comunidade produzem queijos, de forma artesanal, e vendem os produtos nas tendas ou mediante encomendas. Também estão presentes as artesãs que não possuem tendas próprias, as mesmas confeccionam peças e deixam expostas nas tendas de outros artesãos, se o produto é comercializado, pagam uma pequena comissão ao dono da tenda (DIÁRIO DE CAMPO, 2018).

A partir do trabalho de campo foi possível identificar a presença de 16 tendas artesanais, cada tenda tem por traz uma família de artesãos, e outros vários trabalhadores que prestam serviços. A época entre outono e inverno é o pico da produção e de comercialização, sobretudo das vestimentas em lã, “[...] já no período de primavera-verão a comercialização diminui, mas a criação das peças não cessa. Vários artesãos tecem peças em lã, para atender à pedidos de encomendas realizadas por clientes de várias cidades do estado, de outros estados e até de outros países" (VARGAS, 2016, p. 29).

São gerados, em torno de, 40 empregos diretos e indiretos, para homens, mulheres, jovens, adultos e idosos Contudo, além da família do artesão, ainda é necessário buscar mão de obra de moradores da localidade, que são, principalmente, as mulheres e dos jovens, que, respectivamente, realizam o acabamento das peças e a confecção dos tecidos nos teares. O trabalho dos jovens e das mulheres da comunidade é indispensável para a produção e acabamento das peças (VARGAS, 2016; DIÁRIO DE CAMPO, 2018).

A Vila Progresso é local de intenso fluxo de pessoas. Os artesãos expõem seus trabalhos na frente de suas propriedades, às margens da BR, que é onde a maior parte dos produtos são comercializados, além das feiras e pontos específicos (DIÁRIO DE 
CAMPO, 2018). Os artesões da Vila Progresso apontam que desde o início de suas tendas até a atualidade uma série de mudanças acorreram, sobretudo, no que diz respeito ao processo de produção e na diversificação dos produtos, sendo estas, estratégias de produção e reprodução social que possibilitaram sua permanência (DIÁRIO DE CAMPO, 2018).

No início, os artesãos desenvolveram-se com técnicas tradicionais, passadas de geração a geração, transmitidas, sobretudo, pelas mulheres artesãs. Com o passar dos tempos, os produtos foram diversificados, trazendo novos elementos. Somando-se aos trabalhos em lã o couro e a madeira, com o intuito de atende as demandas dos consumidores, expandindo seu mercado e consumidores. Nesse âmbito, Santos (2006, p. 221) enfatiza que "A cultura, forma de comunicação do indivíduo e do grupo com o universo, é uma herança, mas também um reaprendizado das relações profundas entre o homem e o seu meio".

Os proprietários dos estabelecimentos cuidam da comercialização das peças nas tendas/lojas e realizam o atendimento ao cliente. Nesse sentido, os artesãos proprietários organizam os locais de comercialização, os varais colocados na frente de suas residências, e negociam com os fornecedores que vendem ou trocam produtos. Existe uma relação de troca de produtos em lã confeccionados na comunidade (DIÁRIO DE CAMPO, 2018).

Referente ao trabalho com artesanato e a transmissão desse saber tradicional Tedesco (2010, p. 156), se remete “os saberes da mão". Nesta perspectiva o autor aponta que:

Os saberes da mão, expressos e materializados em formas consideradas de artesanato, encontram canais mercantis, com nichos de mercado constituídos na região e ganham expressão de seus confeccionistas como um aprender fazendo ou, então, um fazer-aprendendo, ainda que o feito e aprendido sofram alterações e influências por razões variadas. É nesse sentido que a noção de transmissão de saberes está muito enraizada no horizonte do artesanato. A dinâmica do artesanato, em sua confecção e em sua materialidade, faz com que a fronteira entre o 
material e o imaterial se torne mais tênue; ele vivifica identidades, testemunho material e imaterial da cultura através do uso, dos objetos, do conhecimento, significado, utilidade e aprendizado. $\mathrm{O}$ fazer à mão revela estilo de vida, dimensão do rústico, por isso sua correspondência com o rural, porém não só. Os objetos [...] fazem parte de seu horizonte cultural de longa data. Isso é muito valorizado na esfera mercantil [...].

Os produtos confeccionados artesanalmente possuem uma relação com a vida da comunidade que os produz. O fazer manual possui um sentido prático, o aprendizado desse processo é informal e ocorre através da observação e da prática de aprender a fazer, fazendo (MARTINS, 1973). No fazer artesanal ocorre uma integração com a estrutura social do território onde os artesãos produzem os objetos, ocasionando uma vinculação aos hábitos e a forma de vida dos mesmos (RIOS, 196-).

O destaque das produções e comercializações das tendas na comunidade são produtos fabricados em lã, feitos pelos artesãos/família do local e em alguns casos por artesão contratados de forma temporária. Em muitas tendas foi possível verificar que os artesãos utilizam técnicas tradicionais na confecção das vestimentas em lã, contudo, estão presentes aqueles que buscam modernizar as vestimentas, por exemplo, comprando equipamentos mais modernos e sofisticados para auxiliar no processo produtivo e diversificando o designer e desenhos das peças. Além disso, os artesões, os quais também são tendeiros, inseriram em sua comercialização produtos diversificados, visando atender ao público consumidor e, especialmente, aos turistas, e assim, obter uma maior geração de renda (DIÁRIO DE CAMPO, 2018).

Os principais produtos em lã confeccionados pelos artesãos são: palas para adultos e crianças, capinhas femininas, acolchoados, tocas, golas, boinas, meias, mantas, luvas, pelerines, xales, xergões e pelegos. Além destes, são comercializados no local artigos comprados e/ou trocados com fornecedores por peças em lã como: tapetes, puffs e bancos em couro, bancos e mesas rústicas em madeira, chinelos em couro e ovelhinhas de lã, relógios e gamelas em madeira, caixas de mdf forradas e decoradas, facas, 
mateiras em couro, cuias, bombas de chimarrão e vários outros itens de decoração feitos em lã, couro ou madeira (VARGAS; CANCELIER, 2018).

A diversificação nas tendas, objetiva atrair os turistas e consumidores, que procuram objetos rústico, autênticos e tradicionais, em função de uma aproximação com o modo de vida do campo (VARGAS; CANCELIER, 2018). A esse respeito Canclini (1983, p. 66), lembra que o produto artesanal rústico atrai os turistas de fora e levam um objeto que represente o lugar que esteve remetendo a cultura do local. O autor lembra que os turistas, possuem uma “[...] fascinação pelo nostálgico, rústico e natural, uma das motivações mais invocadas pelo turismo".

Segundo os depoentes, a comercialização artesanal além de ocorrer na tenda, também atende a pedidos, seja de lojas de produtos gauchescos ou agropecuárias, para o todo o estado do RS e outros estados, como Santa Catarina e Paraná. Havendo, de acordo com a fala dos artesãos, um crescimento significativo dos produtos artesanais em lã e demais produtos em couro e madeira, comercializados nas tendas abertas ao público (DIÁRIO DE CAMPO, 2018). O mosaico de imagens da figura 3 mostra um tear e a exposição dos palas, produzidos e disponíveis para comercialização na Vila Progresso.

Com a realização do trabalho de campo, foi notório que a atividade artesanal passou por várias transformações ao longo do tempo na Vila Progresso. No começo o processo artesanal da confecção da lã era bem mais trabalhoso e pesado, demandando um tempo bem maior para realização do processo de produção. Com o passar do tempo, as técnicas, tecnologias e habilidades foram, aos poucos, tornando o processo mais rápido, fácil e leve, conseguindo assim, uma maior produção com alta qualidade (DIÁRIO DE CAMPO, 2018). A partir do mosaico de imagens da figura 2, é possível observar um tear e a exposição dos palas, produzidos e disponíveis para comercialização na Vila Progresso.

Houve mudanças em relação aos teares, rocas e as máquinas de costura, onde equipamentos mais rústicos deram lugar a outros modernos, contribuindo para uma maior agilidade no processo de acabamentos das peças em lã, por exemplo. Segundo 
os artesãos, as principais mudanças na atividade do artesanato em lã na Vila Progresso estão relacionadas aos teares e na utilização de uma lã de melhor qualidade para a confecção das peças. Tais mudanças ocorreram de forma consciente e de acordo com a busca dos artesãos, no sentido de ampliar a quantidade e o rendimento na criação das peças, como consequência das mesmas, uma terceira questão sofreu alteração (DIÁRIO DE CAMPO, 2018).

Figura 2 - Tear, palas e chaveiros confeccionados e comercializados na Vila Progresso
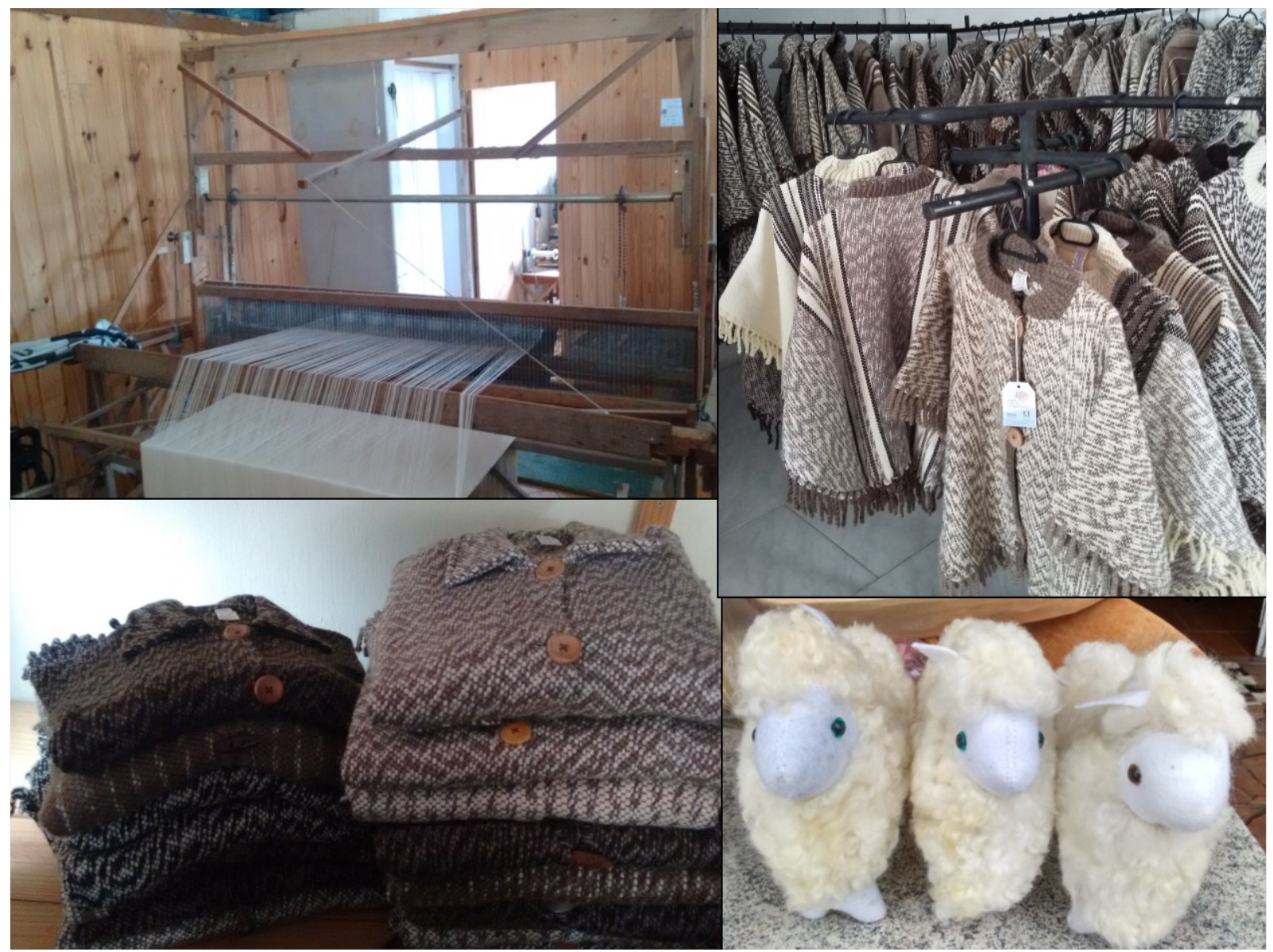

Fonte: Acervo particular das autoras (2018)

No que tange ao aperfeiçoamento das técnicas de produção do artesanato, conforme visualizado no trabalho de campo, a construção acontece por meio dos próprios artesãos. Os mesmos vão articulando estratégias de produção, de acordo as transformações e melhoramentos das técnicas e suas percepções do processo produtivo, bem como, das demandas dos consumidores (DIÁRIO DE CAMPO, 2018). Com as exigências desses "novos consumidores" as peças confeccionadas, de maneira 
artesanal, passaram a ser significativas no mercado, em função do aspecto simbólico a elas conferido (CANCLINI, 1983).

No que diz respeito a demanda do trabalho coletivo, que ocorria em função do processo de lavagem da lã, não foi mais necessária, deixando de existir a partir do momento em que os artesãos optaram por comprar a lã pronta, já lavada, necessitando somente do processo de cardagem e de fazer o fio. Mas, as práticas de reciprocidade continuaram existindo no local, em função da troca de saberes e da aprendizagem conjunta, onde uma artesã ensinava a outra as técnicas de costura e os homens ensinavam os demais a arte de tecer nos teares rústicos de madeira (DIÁRIO DE CAMPO, 2018).

As estratégias simples, mas eficazes, de comercialização das peças em lã demonstram a busca de alternativas de homens e mulheres do campo, para obter rendimento econômico a partir do seu saber-fazer artesanal. Ações como estas criam alternativas de trabalho e renda nas comunidades, onde as famílias com poucos recursos econômicos e pequena área de terra, muitas vezes, utilizam-se de seus próprios saberes para construir alternativas de renda para o núcleo familiar, afim de, manter-se no meio rural (TEDESCO, 2013; CANCLINI, 1983).

Essa mudança trouxe uma séria de adaptações, modificando alguns materiais utilizados e o seu trabalho, e em alguns casos mecanizando o processo de produção. Essas mudanças originaram resultados positivos para os artesãos visitados (DIÁRIO DE CAMPO, 2018). Indo ao encontro com os resultados de Tesdeco (2010, p. 146):

A forma integrada (entre grupos de unidades familiares e com dinâmicas de identidade local/regional) de produtos fabricados com matérias-primas produzidas nas unidades locais [...] expressa imbricação mercantil com universos culturais, saberes cristalizados e transmitidos entre gerações, readaptados em razão das aprendizagens, tendências, condições objetivas das unidades, agregação de valores de um produto a outro [...]. 
Canclini (1983) aborda que o mercado de produtos artesanais já não é mais específico do artesanato, outros artigos são inseridos para comercialização, que não são confeccionados pelos artesãos. A afirmação deste autor pode ser visualizada nas tendas dada Vila Progresso, onde vários produtos foram inseridos com o tempo, com o intuito de satisfazer os consumidores que tem apreço pelas tradições gaúchas.

Dessa forma, muitas tendas começaram a diversificar seus produtos, sendo oriundos do artesanato comprado de fornecedores, como bancos de madeira, tapetes em couro, chaveiros, gamelas de madeira, puffs de couro, facas, atendendo, dessa maneira, a todos os movimentos de consumo. A figura 3 mostra a grande diversidade de produtos comercializados na Vila Progresso.

Figura 3 - Diversificação dos produtos comercializados na Vila Progresso

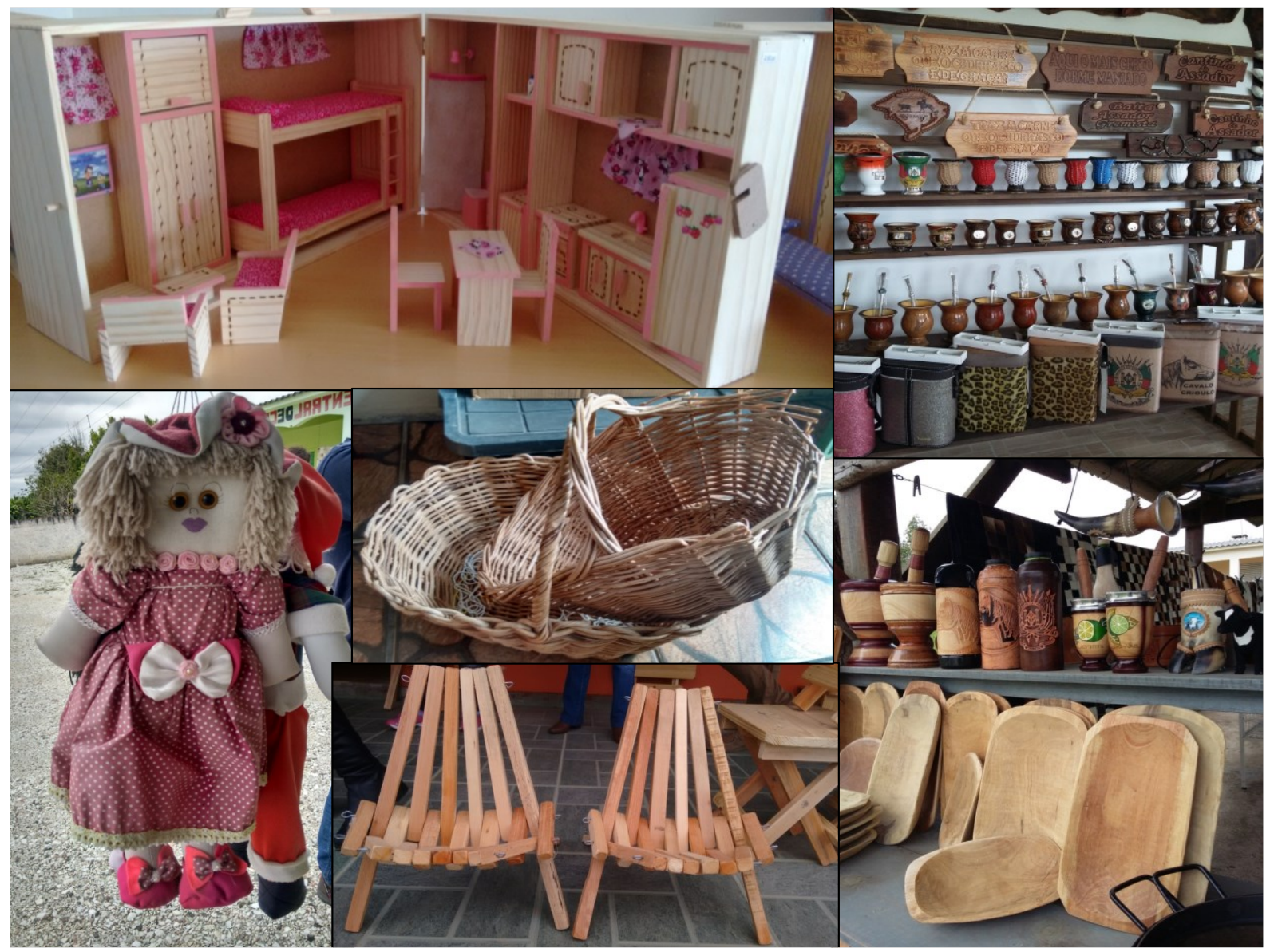

Fonte: Acervo particular das autoras (2018) 
A diversificação dos produtos, que objetivava satisfazer os consumidores, trouxe, por exemplo, os itens em couro e madeira. Com o decorrer da visitação nas tendas durante a realização do trabalho de campo, foi observado que existe a relação de trocas dos produtos em lã, que são confeccionados pela comunidade, pelos de couro e madeira, que são oriundos de artesãos de outros lugares. Ampliando assim, a disponibilidade de produtos comercializados na Vila Progresso e a geração de renda. Cabe ressaltar que, diferente dos produtos em lã que possuem grande procura no período de inverno, os artefatos de couro de madeira possuem demanda durante todo o ano, tendo assim, a manutenção da geração de renda durante todo o ano. A figura 4 mostra a diversidade de produtos em couro, como puffs e tapetes, e os tapetes de lã de ovelha.

Figura 4 - produtos em couro e lã de ovelha, comercializados na Vila Progresso.



Fonte: Acervo particular das autoras (2018) 
Muitos desses produtos possuem um valor sentimental tanto para quem produz e vende, como também para quem compra. Conforme explica Palma (2004), para quem consome esses produtos no mercado existe um valor de compra do produto e um valor de uso do mesmo, baseada em costumes e tradições de uma dada população, onde o produto torna-se simbólico, tendo em vista o atribuído da memória e da tradição.

A partir das conversas realizadas no trabalho de campo, tanto com artesãos quanto com compradores que se encontravam no local no momento da pesquisa, foi possível observar que, além do valor econômico gerado pelos produtos, também para ambos uma relação de identidade materializada no produto (DIÁRIO DE CAMPO, 2018). Nesse sentido, concorda-se com Tedesco (2010, p.152), "produzir, vender e consumir são esferas não apenas alimentadas pela lógica econômica [...]".

Enfim, toda essa movimentação produtiva e mercadológica ocorre em função de um símbolo (BOURDIEU, 2007), são criadas sinergias, uma construção que expressa um significado social, tem uma representação e uma intencionalidade, é representativo para um determinado grupo e tem a realidade social por base, compreendendo e levando sentido às ações, gestos, rituais e manifestações verbais. Nesse sentido, os grupos possuem uma identidade com tal artigo.

Ou seja, muitas vezes quem compra um artesanato, ao visualizar o produto, é acometido por muitas lembranças do seu passado, de seus avós, seus pais, sua região, etc., fazendo com que sua identidade, muitas vezes adormecida, seja acesa novamente, pelo simples fato da compra de um objeto, que fez parte de sua infância, de sua história. Essa identidade também está relacionada aos símbolos dos produtos que os artesãos da Vila Progresso produzem e comercializam, são parte de sua história e por isso são também bens simbólicos (BOURDIEU, 2007).

Por fim, é preciso destacar que, além dos produtos, das relações simbólicas, das técnicas de produção e da construção e ou reconstrução da identidade desses artesãos, também ocorreram mudanças na forma de organização e na dinâmica e a infraestrutura das tendas. Tais mudanças tiveram como objetivo criar estratégias que tornem os produtos atrativos para os consumidores e para atender melhor os clientes. 
Dessa forma, as tendas foram modificadas e ampliadas, gerando uma melhor organização e diversificação dos produtos, as trocas comerciais também foram ampliadas, visto que, passou até dos limites do nosso estado, tornando os produtos visíveis e criando clientes fixos.

\section{CONSIDERAÇÕES FINAIS}

Analisando o estudo realizado na comunidade rural de Vila Progresso, percebemos que existe na comunidade uma identidade cultural, onde várias memórias, histórias, saberes e tradições têm sido acionadas, a fim de formar um contexto comercial onde os produtos artesanais estão em movimento, conectando coisas, pessoas, lugares e culturas, fatores que acabam por influenciar mudanças no aspecto produtivo das peças, transformando inclusive o sentido de uso dos produtos. Através do seu simbolismo os produtos artesanais são capazes de acionar as memórias coletivas, tanto pelos artesãos, os quais foram capazes de reproduzir os conhecimentos de outros, realizados no passado, quanto pelo sujeito que compra tais produtos.

O mercado de artigos artesanais cresceu e diversificou-se, pelo fato de proporcionar, o resgate da história, da tradição, através dos produtos produzidos e comercializados na referida comunidade rural. Nesse sentido, inúmeras transformações ocorrem ao longo do tempo na comunidade rural de Vila Progresso, Caçapava do Sul/RS.

Com o passar dos anos, conforme apreendida com a realização do trabalho de campo, é notório uma considerável ampliação nos produtos confeccionados e comercializados, entre eles os produtos simbólicos, além a ampliação do público que busca estes itens. O que antes o comércio era restrito ao púbico local e os que passavam pela BR - 290, atualmente existe uma forte troca no fluxo comercial e ampliação do mercado consumidor.

Também foi observada uma grande mudança no processo de confecção dos produtos, onde, foram inseridas novas técnicas e tecnologias no processo produtivo, gerando assim, 
maior produção e diversificação dos itens. Foram inseridas, aos poucos, outras peças em lã e também itens em couro e madeira, visando assim atender ao mercado consumidor e tornar a tenda mais atrativa e diversificada aos olhos dos turistas.

Considera-se essencial, intensificar o reconhecimento e a valorização dos saberes tradicionais dos artesãos da comunidade rural de Vila Progresso, os mesmos são provenientes de uma longa história e vem permitindo a permanência e fortalecimento destes ao longo dos anos. Os artesãos precisam manter seus saberes, diante da diversificação dos produtos comercializados nesta comunidade, para assim, não perderem a essência que constitui a comunidade.

Neste cenário, o consumidor teve e tem papel fundamental nas estratégias comerciais das tendas. A partir das demandas dos clientes, os artesãos inserem produtos diversificados, que são artesanais e simbólicos do gaúcho, abarcando as novas dinâmicas de mercado desses artigos. Essas estratégias exigiram dos artesãos, comerciantes e tendeiros, adaptações quanto ao seu trabalho, ampliação do local de comercialização e dos produtos comercializados.

Por fim, salientamos a evolução da comunidade de Vila Progresso, com a produção artesanal e a ampliação dos produtos nas tendas. Onde, mesmo com uma série de dificuldades no cenário de produção e/ou comercialização, houve uma significativa melhoria da qualidade de vida das famílias, que ocorreu através da confiança dos artesãos em seu trabalho e saberes.

\section{AGRADECIMENTOS}

Agradecemos aos artesãos da comunidade rural de Caçapava do Sul/RS pela disponibilidade de tempo para as visitas e conversas.

\section{REFERÊNCIAS}

ARRUDA, D. O.; et. al. Artesanato com lã de ovinos, turismo e desenvolvimento local. PASOS. Revista de Turismo y Patrimônio Cultural. Vol. 11, n. 4, 2013. 
BENCKE, G A.; CHOMENKO, L. D.; SANT'ANNA, M. O que é o Pampa? IN: Nosso Pampa Desconhecido. CHOMENKO, L.; BENCKE, G. A. (Org). Fotografias: Adriano Becker Porto Alegre: Fundação Zoobotânica do Rio Grande do Sul, 2016, p. 17 - 27.

BEZZI, M. L. Região como foco de identidade cultural. Geografia, Rio Claro, Vol. 27 (1), p. 5 - 19, 2002. Disponível em:

https://www.periodicos.rc.biblioteca.unesp.br/index.php/ageteo/article/view/1732/52 43. Acesso em: 29 de fev. 2020

BOURDIEU, P. A economia das trocas simbólicas. Vários Tradutores. $6^{a}$ ed. Editora Perspectivas. São Paulo, 2007. p. 361.


Bertrand Brasil LTDA. Rio de Janeiro, 1989. 322 p.

CAETANO, J. N. A Influência Cultural Portuguesa na reorganização do espaço da Microrregião Geográfica de Cruz Alta/ RS. 2012. Dissertação (Mestrado em Geografia). Universidade Federal de Santa Maria/ RS.

\section{CANCLINI, N. G. As culturas populares no capitalismo. São Paulo: Editora} Brasiliense, 1983.

CLAVAL, P. A Geografia Cultural. Florianópolis: Ed. da UFSC, 1999.

CORRÊA. R. L. Sobre a geografia cultural. Instituto Histórico e Geográfico do Rio Grande do Sul. 2009. Disponível em: http://ihgrgs.org.br/artigos/contibuicoes/Roberto\%20Lobato\%20Corr\%C3\%AAa\%20\%20Sobre\%20a\%20Geografia\%20Cultural.pdf. Acesso em: 29 de fev. 2020

CORRÊA, R. L.; ROSENDAHL, Z. Geografia Cultural: introdução à temática, os textos e uma agenda. In: CORRÊA, R. L.; ROSENDAHL, Z. (Org.). Introdução à Geografia Cultural. Rio de Janeiro: Bertrand Brasil, 2003. p. 9-18

COSGROVE, D. A Geografia está em toda parte: cultura e simbolismo nas paisagens humanas. In: CORRÊA, R. L.; ROSENDAHL, Z. (Org.). Paisagem, Tempo e Cultura. Rio de Janeiro: Ed. Da UERJ, 1998, p. 92-123.

COSGROVE, D. Em direção a uma Geografia cultural radical: Problemas da Teoria. In: CORRÊA, R. L.; ROSENDAH, L. Z. (Org). Introdução à Geografia Cultural. Rio de Janeiro, Bertrand Brasil, 2003, p. 103 - 134. GOLDENBERG, M. A arte de pesquisar: como fazer pesquisa qualitativa em ciências sociais. $8^{a}$ ed. Rio de Janeiro - São Paulo: RECORD, 2004.

HAESBAERT, R. O mito da desterritorialização: do "fim dos territórios" à multiterritorialidade. Rio de Janeiro: Bertrand Brasil, 2004. 
HESPANHOL, R. A. de M. A contribuição do trabalho de campo para a pesquisa cientifica. In: DE DAVID, C.; WIZNIEWSKY, C. R. F. Agricultura e transformações socioespaciais: olhares geográficos e a pesquisa de campo. Porto Alegre: Evangraf/Jadeditora, 2015, p. 47-57.

IBGE, Instituto Brasileiro de Geografia e Estatística. Brasil. Rio Grande do Sul.

Caçapava do Sul. 2017. Disponível em: https://cidades.ibge.gov.br/brasil/rs/cacapavado-sul/\%3E. Acesso em: 14 mar. 2019.

IBGE, Instituto Brasileiro de Geografia e Estatística. Mapa de Biomas e Vegetação: 2004. Disponível em: https://www.ibge.gov.br/geociencias/informacoesambientais/estudos-ambientais/15842-biomas.html?=\&t=acesso-aoproduto\#sub_geociencias\%3E.. Acesso em: 27 de fev. 2020.

LEITE, R. P. Modos de vida e produção artesanal: entre preservar e consumir. In: Olhares itinerantes: reflexões sobre artesanato e consumo das tradições. P. 27 - 41. Artesanato Solidário/Central ArteSol. São Paulo, 2005.

LIMA, R. Artesanato de tradição: cinco pontos em discussão. In: Olhares itinerantes: reflexões sobre artesanato e consumo das tradições. P. 13 - 26. Artesanato Solidário/Central ArteSol. São Paulo, 2005.

MARAFON, G. J. O trabalho de campo como um instrumento de trabalho para o investigador em geografia agrária. In: RAMIRES, C. De l; PESSÔA, V. L. S. (orgs). Geografia e pesquisa qualitativa: nas trilhas da investigação. Uberlândia: Assis, 2009, p. 379-394.

MARTINS, S. Contribuição ao estudo científico do artesanato. Belo Horizonte: Imprensa Oficial, 1973. 100 p.

MARCONI, M. de A.; Lakatos, E. M. Fundamentos de metodologia científica. $5^{a}$ edição - São Paulo : Atlas 2003.

MATOS, P. F. de; PESSÔA, V. L. S. Observação e entrevista: construção de dados para a pesquisa qualitativa em geografia agrária. In: RAMIRES, C. De l; PESSÔA, V. L. S. (orgs). Geografia e pesquisa qualitativa: nas trilhas da investigação. Uberlândia: Assis, 2009, p. 279-291.

MMA, MINISTÉRIO DO MEIO AMBIENTE DO BRASIL. “PAMPA”. Avaliação e ações prioritárias para a conservação da biodiversidade da Mata Atlântica e Campos Sulinos. Publicação avulsa do MMA, 2000. Disponível em https://www.mma.gov.br/biomas/pampa.html. Acesso em: 28 de fev. 2020.

MELLO, C. I. O artesanato rural na dinâmica do desenvolvimento territorial - entre a preservação e a comercialização. Revista IDeAS. v.9, n. 1, 2015. 
NETO, H. B; BEZZI, M. L. A região cultural como categoria de análise da materialização da cultura no espaço gaúcho. RA 'E GA - espaço geográfico em análise, Curitiba, n. 17, p. 17-30, 2009. Editora UFPR. Disponível em:

https://revistas.ufpr.br/raega/article/view/11862/10662. Acesso em: 29 de fev de 2020.

PREFEITURA DE CAÇAPAVA DO SUL - RS. Cidade. S/d. Disponível em: http://www.cacapava.rs.gov.br/. Acesso em: 17 mar. 2019.

OLIVEN, R.G. A parte e o todo: a diversidade cultural no Brasil-nação. $2^{a}$ Ed. Revista e ampliada. Editora Vozes. Petrópolis, RJ. 2006. 228 p.

OLIVEN, R.G. O renascimento do gauchismo. In: Gonzaga, S. I. FISCHER, L. A (Orgs.). Nós os gaúchos. Editora UFRGS, 1998. 300 p.

RAMOS, H. R. D.; PESSÔA, V. L. S.. Encontros e desencontros das informações: o caminho metodológico da pesquisa. In: PESSÔA, V. L. S.; RÜCKERT, A. A.; RAMIRES, J. C. de L. (orgs). Pesquisa qualitativa: aplicações em Geografia. Porto Alegre: Imprensa Livre, 2017, p. 432-461.

RIOS, J. A. (Org.) Artesanato e desenvolvimento: o caso cearense. CNI/SESI, [196-].

SANTOS, M. A Natureza do Espaço: Técnica e Tempo. Razão e Emoção. 4. ed. 2. reimpr. - São Paulo: Editora da Universidade de São Paulo, 2006.

TEDESCO, J. C. Modernização, patrimônio cultural e dinâmicas familiares - estratégias camponesas e territoriais de desenvolvimento no Centro-Norte do RS. RURIS. V. 4, n. 1, 2010. Disponível em:

https://www.ifch.unicamp.br/ojs/index.php/ruris/article/view/709/574. Acesso em: 23 nov. 2018.

TEDESCO, J. C. O futuro do passado: etnicidade, comércio e vida rural: tradições culturais em rotas turísticas. Editora Letra e Vida. Porto Alegre 2013, 144 p.

VARGAS, D. L. Tecendo tradição: artesanato e mercado simbólico de uma comunidade rural do pampa gaúcho. Tese de Doutorado. Programa de PósGraduação em Extensão Rural. Santa Maria: UFSM, 2016.

VARGAS, D. L.; CANCELIER, J. W. Artesanato e mercado simbólico dos produtos gauchescos: o caso da Vila Progresso em Caçapava do Sul/RS. In: Revista Brasileira de Gestão e Desenvolvimento Regional, 2018, v.14(2), p. 228-246. Disponível em:

https://www.rbgdr.net/revista/index.php/rbgdr/article/view/3592. Acesso: 13 jan. de 2020. 
VIVES, V. A beleza do cotidiano. In: RIBEIRO, B. et al. $\mathbf{O}$ artesão tradicional e seu papel na sociedade contemporânea. Rio de Janeiro: FUNARTE/InstitutoNacional do Folclore, 1983.

WAGNER, P. L.; MIKESELL, M. W. Os temas da Geografia Cultural. In: CORRÊA, R. L.; ROSENDAHL, Z. (Org.). Introdução à Geografia Cultural. Rio de Janeiro: Bertatand Brasil, 2003. p. 27-62.

WWC, World Crafts Council. Artesanato. Disponível em: Acesso em: https://www.wccinternational.org/. Acesso em: 13 de dez. de 2018.

\footnotetext{
' Foi necessária a construção de poços porque a comunidade sofria no período de verão com falta de água.

ii A qual atende alunos até o quarto ano do primário, os demais alunos são levados pelo transporte público para uma escola que possui ensino fundamental e médio, em torno de $15 \mathrm{~km}$ da Vila.

iii Conta com um olival em produção, lagar que produz o azeite de oliva Prosperato, o Empório Prosperato que comercializa o azeite produzido e outros produtos e a empresa Tecnoplanta com viveiro de mudas florestais. Gera empregos diretos e alguns empregos temporários na época de colheita das frutas. O fato da proximidade com a BR 290 foi um dos fatores responsáveis pela instalação na fábrica na Vila Progresso.
} 